\title{
Overlege Danielssen, antar jeg?
}

\author{
Nylig var jeg i Bergen og passerte «Overlege Danielsens hus». Men det var noe som ikke stemte. \\ Skrev ikke Danielssen seg med to s-er?
}

Daniel Cornelius Danielssen (1815-94) er en av Bergens store sønner (fig 1) (1). Han var lege, naturforsker og politiker, og hans navn er blant annet knyttet til utforskning av leprasykdommen. Men hvordan skal navnet skrives? I flere kilder fremgår det at han skrev etternavnet med to s-er (1-6).

Jeg har informert Eiendomsavdelingen ved Universitetet i Bergen om disse opplysningene, og de har lovet å sette opp et nytt skilt ved inngangen til «Overlege Danielssens hus»-med riktig skrivemåte.

I våre dager er denne skrivemåten sjelden. Det er kun 20 personer i Norge med etternavn Danielssen - mens enkelt-svarianten deles av ca. 5500 (7).

\section{Hanssen og Hansen}

En av Danielssens svigersønner var Gerhard Armauer Hansen (1841-1912) (fig 2), som slo inn på samme felt som sin svigerfar - utforskning av leprasykdommen. Man kan trygt si det ble vellykket. Han tilhører den lille krets av norske

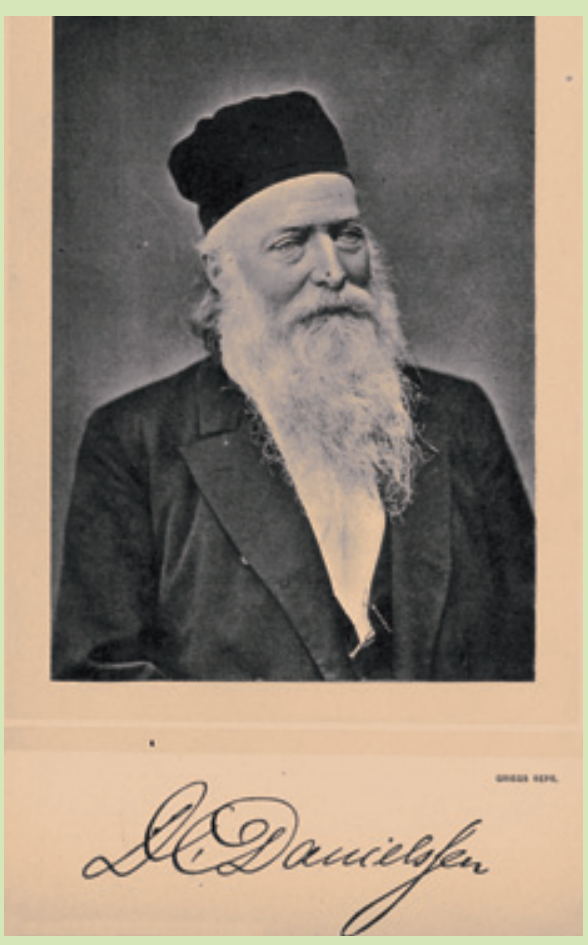

Figur 1 Daniel Cornelius Danielssen (1815-94) (1) leger som har fått en sykdom oppkalt etter seg: Lepra kalles også «Hansens sykdom» $(8,9)$.

Armauer Hansen vokste opp i en tallrik barneflokk. En av brødrene var Klaus Hanssen (1844-1914) (fig 3). Også han ble en av sin samtids fremste leger. Særlig gjorde han seg bemerket $i$ arbeidet mot tuberkulose. Disse brødrene skrev etternavnet sitt på forskjellig vis - med henholdsvis én og to s-er. «Armauer Hansens hus» i Bergen er riktig skrevet.

\section{Konklusjon}

Skrivemåten av eldre navn kan by på problemer, fordi den ofte varierer i ulike kilder. Ortografien var ikke sjelden vaklende. Men hos Danielssen og Hans(s)en-brødrene ser det ut til å være konsistent, og det får vi rette oss etter.

\section{Erlend Hem}

erlend.hem@medisin.uio.no

Tidsskriftet

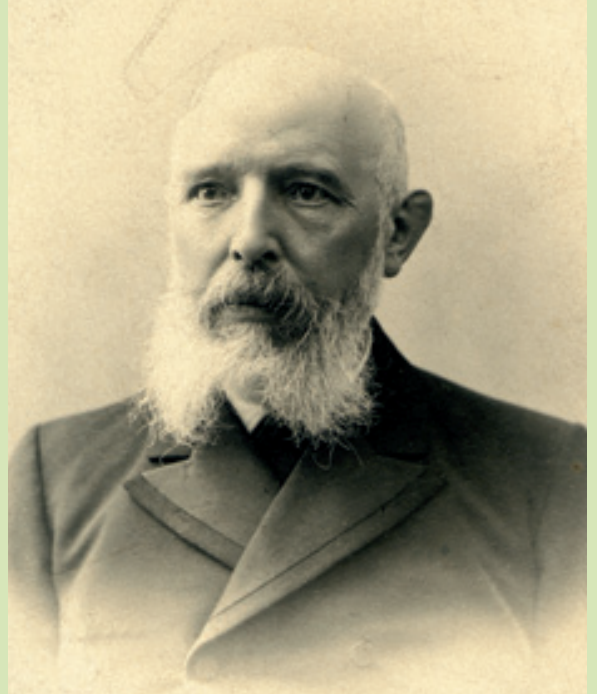

Figur 2 Gerhard Armauer Hansen (1841-1912). Foto Lepramuseet - Bymuseet i Bergen
Litteratur

Daniel Cornelius Danielssen. Nekrolog. Medicinsk Revue 1894; 11: 193-5.

2. Arkivverket. Månedens dokument november 2003 Hvordan spres kolera - smittestoff eller miasmer? www.arkivverket.no/originalbilder/m_nov_2003_ 14_1.jpg (29.12.2008)

3. Danielssen DC. Zur Therapie der Lepra. Arch Dermatol Syph 1893; 25: 3-26.

4. Overlæge, dr. med. et philos. Danielssen. Nekrolog. Tidsskr Nor Lægeforen 1894; 14: 381-4.

5. Dr.med. \& phil. D. C. Danielssen. Nekrolog. Norsk Mag Lægevidensk 1894; 55: 762-4.

6. Hansen GA. Daniel Cornelius Danielssen. Nekrolog. Arch Dermatol Syph 1894; 29: 172-5.

7. Statistisk sentralbyrå. www.ssb.no/navn (29.12.2008).

8. Hansens sykdom. Aschehoug og Gyldendals Store norske leksikon. 4. utg. www.snl no/article html ? id=582238 (29.12.2008).

9. Irgens LM. Oppdagelsen av leprabasillen. Tidsskr Nor Lægeforen 2002; 122: 708-9.

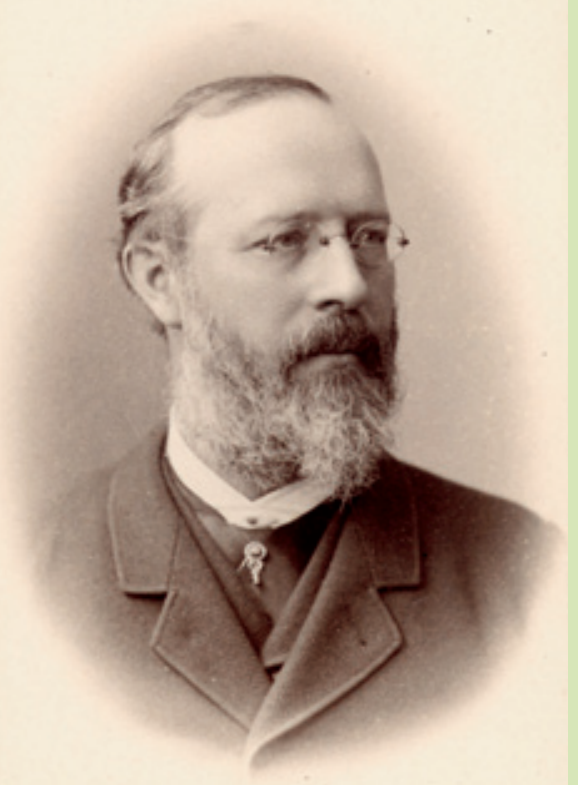

Figur 3 Klaus Hanssen (1844-1914) fotografert i 1893. Foto @ Stortingsarkivet/fotograf L. Szacinski 